INOBIS: Jurnal Inovasi Bisnis dan Manajemen Indonesia

Volume 1, Nomor 4, September 2018

Meina Wulansari Yusniar; Sulfi Jikrillah

\title{
Reaksi Pasar Modal dan Pasar Uang Dunia Terhadap Pemilihan Presiden Amerika Serikat 2016 (Studi Pada 8 Pasar Saham Dunia dan 14 Kurs Mata Uang Teraktif )
}

\author{
Meina Wulansari Yusniar ${ }^{1}$, Sufi Jikrillah ${ }^{2}$ \\ Universitas Lambung Mangkurat \\ mwyusniar@unlam.ac.id
}

\begin{abstract}
Abstrak
Peristiwa Pemilihan Presiden Amerika Serikat selalu mendapat perhatian dari dunia karena akan memberikan dampak terhadap perekonomian dunia. Penelitian merupakan penelitian event study yang bertujuan untuk mengetahui apakah Pasar Modal dan Pasar Uang dunia bereaksi terhadap peristiwa pemilihan Presiden Amerika Serikat pada tanggal 8 November 2016. Metode yang digunakan adalah uji beda dengan periode pengamatan 5 hari sebelum peristiwa dan 5 hari setelah peristiwa. Data yang digunakan adalah Harga Saham Gabungan dari 8 negara dan 14 nilai mata uang asing terhadap dollar. Hasil Penelitian menunjukkan bahwa tidak terdapat perbedaan yang signifikan indeks harga saham gabungan sebelum dan sesudah peristiwa. Namun terdapat perbedaan yang signifikan kurs nilai mata uang sebelum dan sesudah peristiwa.
\end{abstract}

Kata kunci: studi peristiwa, pemilihan presiden, harga saham gabungan, nilai tukar

\section{Pendahuluan}

Risiko politik merupakan salah satu faktor penting yang mempengaruhi operasi Pasar keuangan suatu negara. Secara umum risiko politik merupakan kemungkinan terjadinya kejadian tertentu yang mempunyai dampak negatif terhadap perekonomian suatu negara bahkan negara lainnya yang berhubungan dengan negara tersebut. Risiko Politik dapat berupa Perubahaan Undang-undang, kudeta, pemilihan presiden, atau perubahan rezim di suatu negara. Peristiwa-peristiwa politik sangat berkaitan dengan kestabilan perekonomian suatu negara. Selain itu peristiwa politik dapat menyebabkan menurunnya tingkat kepercayaan investor, jika peristiwa tersebut mengancam stabilitas negara. Hal ini disebabkan karena salah satu faktor investor mau berinvestasi di suatu negara jika stabilitas politiknya kondusif.

Menurut Mendelson (1976), Kinerja pasar saham dan pasar uang dipengaruhi oleh aktivitas pemerintahan dan aktivitas perekonomian secara umum. Hal yang sama juga dikemukakan oleh Zaqi (2006) menyatakan bahwa semakin penting peran pasar modal dan pasar uang dalam kegiatan ekonomi, membuat bursa saham semakin sensitif terhadap peristiwa disekitarnya, baik berkaitan ataupun tidak berkaitan secara langsung dengan peristiwa ekonomi. Artinya adalah pasar modal dan pasar uang disuatu Negara yang merupakan salah satu indikator baik tidaknya perekonomian di sebuah negara tidak terlepas dari berbagai pengaruh lingkungan, baik lingkungan ekonomi maupun lingkungan non ekonomi.

Pengaruh lingkungan ekonomi terbagi atas dua yaitu ekonomi mikro dan ekonomi makro. Untuk lingkungan ekonomi mikro yang sering mendapat respon dari Investor adalah kinerja perusahaan, perubahan strategi perusahaan, pengumuman laporan keuangan atau pembagian dividen perusahaan. Selain itu, perubahan lingkungan ekonomi makro yang terjadi seperti perubahan suku bunga tabungan dan deposito, kurs valuta asing, inflasi, serta berbagai 
INOBIS: Jurnal Inovasi Bisnis dan Manajemen Indonesia

Volume 1, Nomor 4, September 2018

Meina Wulansari Yusniar; Sulfi Jikrillah

regulasi dan deregulasi ekonomi yang dikeluarkan pemerintah, turut berpengaruh pada fluktuasi harga dan volume perdagangan di pasar modal.

Pengaruh lingkungan non ekonomi, walaupun tidak terkait secara langsung dengan dinamika yang terjadi di pasar keuangan tidak dapat dipisahkan dari aktivitas pasar Keuangan. Lingkungan non ekonomi tersebut seperti berbagai isu mengenai kepedulian terhadap lingkungan hidup, hak asasi manusia, serta peristiwa-peristiwa politik kerap kali menjadi faktor utama pemicu fluktuasi harga saham dan perubahan nilai kurs mata uang di pasar keuangan seluruh dunia. Makin pentingnya peran pasar keuangan dalam kegiatan ekonomi, membuat bursa semakin sensitif terhadap berbagai peristiwa disekitarnya, baik berkaitan atau tidak berkaitan secara langsung dengan isu ekonomi.

Salah satu peristiwa politik yang sangat berpengaruh terhadap pasar modal dan pasar uang dunia adalah peristiwa Pemilihan Presiden Amerika Serikat yang terjadi setiap 4 tahun Sekali. Hasil pemilihan Presiden AS ini dapat mempengaruhi kinerja Pasar Saham dan pasar uang seluruh dunia akibat adanya perubahan-perubahan yang terjadi pada kebijakan pemerintah seperti pembelanjaan dan perubahan pajak. Para pelaku pasar keuangan selalu berharap jika mereka dapat menentukan harga saham dan nilai tukar ketika terjadi perubahan politik.

Beberapa penelitian terdahulu memperlihatkan hubungan antara pemilihan presiden dengan kinerja pasar modal dunia. Kabiru, Ochieng dan Kinyua (2015) melakukan peneltian tentang pengaruh pemilihan Umum terhadap return saham pada Nairobi Securities exchange. Hasil Penelitiannya memperlihatkan bahwa reaksi pasar terhadap pemilu bisa sangat negatif dan positif tergantung pada lingkungan pemilihan umum. Peel and Pope (1993) dan Gemmil (1992) menguji Perilaku harga saham selama pemilihan pemerintah di berbagai negara maju, dan mereka menemukan ketidak efisienan harga saham di sekitar waktu pemilihan. Mereka berargumentasi bahwa perubahan dalam administrasi pemerintahan yang disebabkan oleh pemilihan cenderung mempengaruhi kebijakan keuangan atau undang-undang, sehingga secara signifikan mempengaruhi harga saham.

Oehler, Thomas dan Wendt (2009) menguji dampak hasil pemilihan presiden AS terhadap kinerja harga saham pada perusahaan saham A.S. dan sektor industri. Hasilnya menunjukkan bahwa dampak dari pemilihan presiden akan mempengaruhi harga saham dalam jangka panjang dan pasar saham akan mengoreksi harga saham setelah pengumuman pemilihan presiden yang mencerminkan adanya perubahan dalam pemerintahan. Nezerwe (2013), menguji hubungan antara pemilihan presiden dengan Return Saham di Mesir. Pemilihan Presiden yang digunakan adalah Pemilihan Presiden tahun 2005 dan 2012. Hasil penelitian memperlihatkan bahwa kedua peristiwa pemilihan presiden baik tahun 2005 dan 2012 mempunyai dampak yang positif terhadap return saham di pasar modal Mesir.

Di Indonesia sendiri terdapat beberapa penelitian yang memperlihatkan hubungan antara pemilihan presiden dengan kinerja pasar modal Indonesia. Meidawati dan Harimawan (2004) meneliti tentang pengaruh pemilihan umum legislatif Indonesia terhadap return saham, menyimpulkan bahwa terdapat perbedaan nilai rata-rata volume perdagangan saham pada periode sebelum dan sesudah peristiwa Pemilu Legislatif 2004 dan menunjukkan perbedaan yang signifikan antara rata-rata abnormal return (AAR) sebelum peristiwa dengan sesudah peristiwa pemilu legislatif 2004. Hasil yang berbeda ditemukan dalam penelitian Trisnawati (2014) yang menunjukkan bahwa tidak terdapat perbedaan antara ratarata trading volume dan abnormal return sebelum dan sesudah terjadinya peristiwa Pemilihan Presiden Republik Indonesia tahun 2004 dan 2009. Asshodiqi (2015) meneliti reaksi pasar terhadap peristiwa pelantikan presiden 2014 pada tiga jenis indeks. Hasil penelitiannya memperlihatkan bahwa tidak terdapat perbedaan rata-rata abnormal return sebelum dan 
INOBIS: Jurnal Inovasi Bisnis dan Manajemen Indonesia

Volume 1, Nomor 4, September 2018

Meina Wulansari Yusniar; Sulfi Jikrillah

sesudah peristiwa pada ketiga indeks dan tidak terdapat perbedaan trading volume activity yang signifikan hanya terjadi pada Jakarta Islam Indeks (JII).

Selain Pasar Modal, peristiwa pemilihan presiden juga mempengaruhi pasar uang dunia. Ashour dan Sarkar (2014) membahas hubungan antara nilai tukar mata uang asing A.S. dan politik A.S. Hasil penelitian mereka menemukan bahwa nilai tukar mata uang AS menguat terhadap pound Inggris dan euro jika presiden terpilih berasal dari partai republik. Namun untuk mata uang Yen nilai tukar AS menguat jika presiden terpilih berasal dari partai Demokrat. Selain itu hasil penelitian juga menemukan bahwa indeks perdagangan papan atas mengalami kenaikan jika presiden terpilih berasal dari partai Republik. Ochieng (2013) melakukan penelitian mengenai pengaruh risiko politik terhadap nilai tukar di Kenya. Mata uang untuk penelitian adalah, USD, EURO, dan USHS. Peristiwa politik yang diteliti adalah referendum pada bulan Agustus 2010 dan Pemilihan umum pada bulan Maret 2013. Hasil penelitian menunjukkan adanya hubungan yang signifikan antara peristiwa politik dengan mata uang USD. Hal ini memperlihatkan bahwa peristiwa politik memberikan dampak pada depresiasi atau apresiasi USD yang signifikan di Kenya. Hal yang sama juga ditemukan pada penelitian Bernhard dan Leblang (1999), yang mendukung bahwa peristiwa politik berpengaruh terhadap pasar uang global. Para investor akan melihat komitmen dari presiden terpilih yang akan mempengaruhi nilai tukar. Antisipasi bahwa pemerintah akan menerapkan kebijakan tertentu dapat menyebabkan perubahan nilai mata uang. Jika kebijakan dianggap menguntungkan maka nilai tukar akan mengalami penguatan, tetapi jika tidak maka nilai tukar akan mengalami pelemahan.

Dalam tulisan ini, peneliti akan melakukan studi tentang dampak perubahan ekonomi dunia setelah Donald Trump memenangkan pemilihan presiden tahun 2016. Pemilihan Presiden AS merupakan salah satu kunci penting terhadap perubahan ekonomi dunia. Dengan demikian siapa pun yang terpilih menjadi presiden AS akan berdampak terhadap harga saham dunia dan perubahan kurs mata uang dunia. Adanya kemungkinan munculnya presiden AS yang baru membuat para pelaku pasar menaruh harapan yang besar terkait kemajuan perekonomian di dunia. Apabila presiden terpilih dapat membawa perubahan yang positif bagi perekonomian dunia melalui berbagai strategi, kebijakan, serta gebrakan yang inovatif, maka tidak menutup kemungkinan bahwa perubahan positif itu juga dapat berkontribusi terhadap peningkatan perekonomian dunia, sebab perkembangan kegiatan ekonomi di Amerika Serikat dapat dipandang sebagai tolok ukur atau barometer bagi perekonomian di negara- negara lain di Dunia. Peningkatan tersebut pada akhirnya akan mendorong gairah investasi para investor di pasar saham dan pasar uang.

\section{Landasan Teori dan Pengembangan Hipotesis}

\section{Efisiensi Pasar Hipotesis}

Pasar efisien yang ditinjau dari sudut informasi saja disebut dengan efisiensi pasar secara informasi (informationally efficient market) sedang pasar efisien yang ditinjau dari sudut kecanggihan pelaku pasar dalam mengambil keputusan berdasarkan informasi yang tersedia disebut dengan efisiensi pasar secara keputusan (decisionally efficient market). Kunci utama untuk mengukur pasar yang efisien adalah hubungan antara harga sekuritas dengan informasi. Fama (1970) menyajikan 3 macam bentuk utama dari efisiensi pasar berdasarkan ketiga macam bentuk dari informasi, yaitu informasi masa lalu, informasi sekarang yang sedang dipublikasikan dan informasi privat sebagai berikut ini: 
INOBIS: Jurnal Inovasi Bisnis dan Manajemen Indonesia

Volume 1, Nomor 4, September 2018

Meina Wulansari Yusniar; Sulfi Jikrillah

a. Efisiensi pasar bentuk lemah (weakform)

Pasar dikatakan efisien dalam bentuk lemah jika harga-harga dari sekuritas tercermin secara penuh (fully reflect) informasi masa lalu. Bentuk efisiensi pasar secara lemah ini berkaitan dengan teori langkah acak (random walk theary).

b. Efisiensi pasar bentuk pasar setengah kuat (semistrong form)

Dikatakan demikian jika harga-harga sekuritas secara penuh mencerminkan (fully reflect) semua informasi yang dipublikasikan termasuk informasi yang berada di laporan-laporan keuangan perusahaan emiten. Informasi tersebut dapat berupa: 1) Informasi yang dipublikasikan yang hanya mempengaruhi harga sekuritas dari perusahaan yang mempublikasikan informasi tersebut. 2) Informasi yang dipublikasikan yang akan mempengaruhi harga sekuritas sejumlah perusahaan.

c. Efisiensi pasar bentuk kuat (strong form)

Dikatakan demikian jika harga-harga sekuritas secara penuh mencerminkan (fully reflect) semua informasi yang tersedia termasuk informasi yang privat.

\section{Studi Peristiwa atau Event Study}

Menurut Hartono (2010) Event Study atau studi peristiwa merupakan studi yang mempelajari reaksi pasar terhadap suatu peristiwa (event) yang informasinya dipublikasikan sebagai suatu pengumuman. Event Study dapat digunakan untuk menguji kandungan informasi (information content) dari suatu pengumuman dan dapat juga digunakan untuk menguji efisiensi pasar dalam bentuk setengah kuat. Dikatakan memiliki informasi jika suatu pengumuman membuat pasar bereaksi baik itu bereaksi positif maupun bereaksi negative, sebailiknya jika pasar tidak memberikan reaksi maka informasi tersebut tidak memiliki kandungan informasi. Dalam penelitian ini reaksi pasar keuangan dapat dilihat dari adanya perubahan indeks harga saham dan perubahan nilai kurs mata uang.

\section{Pengembangan Hipotesis}

Penelitian ini difokuskan pada reaksi pasar terhadap suatu peristiwa dimana peristiwa yang akan diteliti adalah peristiwa pemilihan Presiden Amerika Serikat pada tanggal 08 November 2016 terhadap indeks harga saham dunia dan kurs mata uang dunia. Pemilihan Presiden Amerika Serikat merupakan salah satu peristiwa yang sangat mempengaruhi kinerja Pasar Saham dan pasar uang seluruh dunia. Hal ini disebabkan karena siapapun yang terpilih menjadi presiden AS akan mengakibatkan perubahan-perubahan yang terjadi pada kebijakan pemerintah seperti pembelanjaan dan perubahan pajak yang juga berdampak terhadap negara lainnya. Para pelaku pasar keuangan selalu berharap jika mereka dapat menentukan harga saham dan nilai tukar ketika terjadi perubahan politik.

Penelitian terdahulu memperlihatkan hubungan antara pemilihan presiden dengan kinerja pasar modal dunia. Kabiru, Ochieng dan Kinyua (2015), Nezerwe (2013) dan Meidawati dan Harimawan (2004) menemukan adanya reaksi pasar terhadap peristiwa pemilihan presiden. Peel and Pope (1993), Gemmil (1992) Oehler, Thomas dan Wendt (2009) menemukan ketidak efisienan harga saham di sekitar waktu pemilihan disebabkan adanya perubahan kebijakan keuangan atau undang-undang, sehingga secara signifikan mempengaruhi harga saham.

Selain Pasar Modal, peristiwa pemilihan presiden juga mempengaruhi pasar uang dunia. Ashour dan Sarkar (2014) menemukan bahwa nilai tukar mata uang AS menguat terhadap pound Inggris dan euro jika presiden terpilih berasal dari partai republik. Namun 
INOBIS: Jurnal Inovasi Bisnis dan Manajemen Indonesia

Volume 1, Nomor 4, September 2018

Meina Wulansari Yusniar; Sulfi Jikrillah

untuk mata uang Yen nilai tukar AS menguat jika presiden terpilih berasal dari partai Demokrat. Ochieng (2013) menemukan adanya hubungan yang signifikan antara peristiwa politik dengan mata uang USD. Berdasarkan teori yang telah dijelaskan diatas dan beberapa penelitian terdahulu, maka hipotesis yang diuji pada penelitian ini adalah :

$\mathrm{H}_{1}$ : Terdapat perbedaan indeks harga saham yang signifikan sebelum dan sesudah peristiwa pengumuman pemilihan presiden AS 8 November 2016

$\mathrm{H}_{2}$ : Terdapat perbedaan Nilai Kurs Mata Uang yang signifikan sebelum dan sesudah peristiwa pengumuman pemilihan presiden AS 8 November 2016

\section{Metode Penelitian}

Jenis penelitian ini adalah penelitan yang menggunakan studi peristiwa (event study yang mempelajari reaksi pasar terhadap suatu peristiwa (event) yang informasinya dipublikasikan sebagai suatu pengumuman. Dalam penelitian ini studi peristiwa yang akan diuji kandungan informasinya adalah peristiwa pemilihan presiden di Amerika Serikat tanggal 08 November 2016. Periode peristiwa yang digunakan dalam penelitian ini adalah selama 10 hari bursa yaitu 5 hari sebelum peristiwa dan 5 hari setelah peristiwa.

Data yang digunakan dalam penelitian ini merupakan data sekunder, yaitu data 16 Indeks Harga Saham dari berbagai Pasar Modal di dunia yang mempunyai pengaruh yang cukup signifikan jika harga saham mereka mengalami pergerakan dan nilai tukar 10 mata uang Asing yang sering digunakan terhadap dollar Amerika Serikat. Menurut Tandelilin (2010), Indeks pasar saham merupakan indikator yang mencerminkan kinerja saham-saham di pasar. Indeks harga saham saat ini dapat dijadikan barometer yang menunjukkan kesehatan ekonomi suatu negara dan dijadikan landasan analisis statistik atas kondisi pasar terakhir. Sedangkan Nilai Tukar menurut Triyono (2008), pertukaran antara dua mata uang yang berbeda, yaitu merupakan perbandingan nilai atau harga antara kedua mata uang tersebut.

Penelitian ini mengamati pergerakan harga saham di Pasar modal dunia dan nilai tukar terhadap dollar untuk menganalisis perbedaan rata-rata indeks harga saham pasar modal dunia dan rata-rata nilai tukar terhadap dollar sebelum dan setelah peristiwa pemilihan Presiden AS.Dalam penelitian ini untuk membuktikan hipotesis I dan II menggunakan uji beda (T-Test) dengan sample berhubungan (paired samples T-Test), uji beda t-test digunakan untuk menentukan apakah dua sampel yang tidak berhubungan memiliki nilai rata-rata yang berbeda. Uji beda t-test dilakukan dengan cara membandingkan perbedaan antara dua nilai rata-rata dengan standar error dari perbedaan rata-rata dua sampel. Tujuan uji beda t-test adalah membandingkan rata-rata dua group yang tidak berhubungan satu dengan yang lain. Apakah kedua group tersebut mempunyai nilai rata-rata yang sama ataukah tidak sama secara signifikan. Sesuai dengan penelitian ini yaitu untuk menganalisis perbedaan antara rata-rata indeks harga saham dunia dan nilai tukar dollar terhadap mata uang asing yang diperoleh para investor antara sebelum dan sesudah peristiwa pemilihan presiden AS, maka pengujian yang cocok dalam penelitian ini adalah dengan menggunakan uji beda ttest. Untuk pengambilan keputusan dalam penelitian ini pertimbangan yang dilakukan sebagai berikut:

1) Jika probabilitas $<0,05$; maka $\mathrm{H} 0$ ditolak artinya terdapat perbedaan variance

2) Jika probabilitas $>0,05$; maka $\mathrm{HO}$ tidak dapat ditolak artinya terdapat kesamaan variance. 
INOBIS: Jurnal Inovasi Bisnis dan Manajemen Indonesia

Volume 1, Nomor 4, September 2018

Meina Wulansari Yusniar; Sulfi Jikrillah

\section{Hasil dan Pembahasan}

\section{Statistik Deskriptif Harga Saham Gabungan 8 Bursa Dunia}

Statistik deskriptif dilakukan untuk memperoleh gambaran secara umum data yang diolah. Hasil pengujian statistik deskriptif dapat dilihat pada tabel 1, sebagai berikut.

Tabel 1

Statistik Deskriptif Harga Saham Gabungan dari 8 Bursa Dunia

\begin{tabular}{ccc}
\hline & Sebelum & Sesudah \\
\hline $\mathrm{N}$ & 8 & 8 \\
Min. & 857,00 & 868,00 \\
Max. & $22.909,00$ & $22.839,00$ \\
Mean & $7.846,00$ & $7.935,00$ \\
\hline Std. Dev. & $\mathbf{7 . 7 5 7 , 1 5}$ & $\mathbf{7 . 7 4 6 , 7 0}$ \\
\hline
\end{tabular}

Sumber: Data diolah, 2018

Berdasarkan pada tabel 1, bahwa rata-rata harga saham gabungan pada 8 (delapan) bursa yang diamati yaitu 7.846 sebelum pengumuman kemenangan Donald Trump dan 7.935 sesudah pengumuman kemenangan Donald Trump sebagai presiden AS menggantikan Barack Obama. Berdasarkan gambar 1 diketahui bahwa harga saham dunia mengalami fluktuasi. Pada saat pengumuman bahwa Donald Trump terpilih menjadi presiden Amerika Serikat, bursa saham dunia mengalami pelemahan turun sekitar 1,86 persen dari hari sebelumnya yaitu 7903 menjadi 7756 pada saat pemilihan presiden. Namun, sehari setelah pengumuman indeks harga saham mulai mengalami peningkatan lagi menjadi 7935.

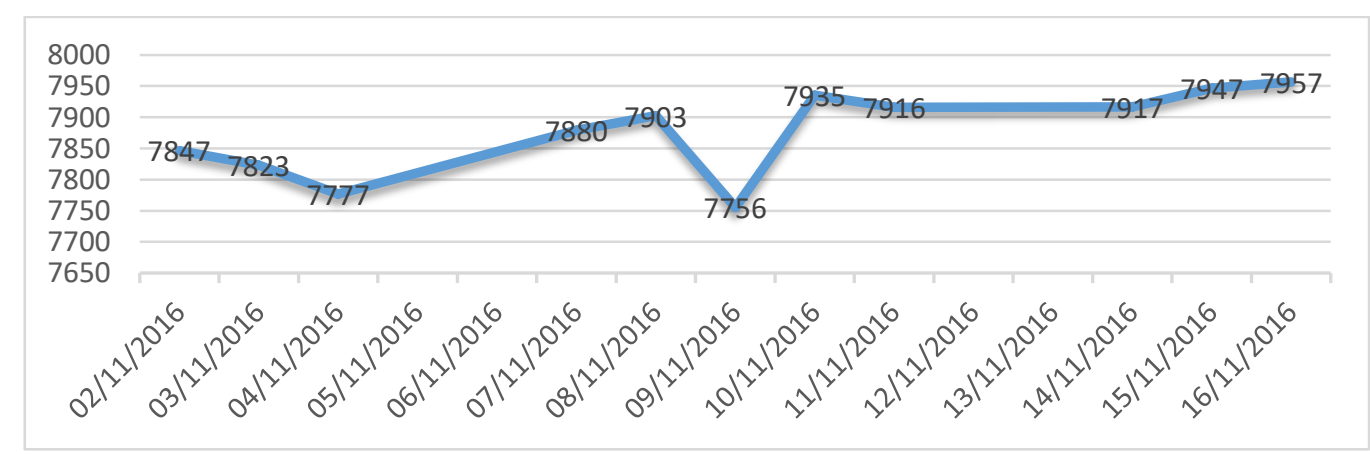

Gambar 1

Pergerakan Rata-rata 8 Bursa Saham Dunia

Tabel 2 memperlihatkan nilai minimum dan nilai maksimum dari masing-masing harga saham gabungan selama periode pengamatan. 
INOBIS: Jurnal Inovasi Bisnis dan Manajemen Indonesia

Volume 1, Nomor 4, September 2018

Meina Wulansari Yusniar; Sulfi Jikrillah

Tabel 2

Statistik deskriptif Harga Saham Gabungan

Selama Periode Pengamatan

\begin{tabular}{lcrrrr}
\hline & N & Minimum & Maximum & \multicolumn{1}{c}{ Mean } & $\begin{array}{c}\text { Std. } \\
\text { Deviation }\end{array}$ \\
\hline JERMAN & 11 & 10259.13 & 10735.14 & 10539.2718 & 166.22683 \\
HONGKONG & 11 & 22222.22 & 22909.47 & 22587.2317 & 245.91108 \\
USA & 11 & 5046.37 & 5294.58 & 5186.8718 & 84.21576 \\
AMSTERDAM & 11 & 856.69 & 882.45 & 869.2745 & 6.84111 \\
TOKYO & 11 & 16251.54 & 17862.21 & 17245.1855 & 436.60824 \\
LONDON & 11 & 1156.89 & 1302.20 & 1230.8482 & 59.41340 \\
AMERIKA & 11 & 2153.42 & 2247.68 & 2205.6191 & 34.48057 \\
SHANGHAI & 11 & 3102.73 & 3210.37 & 3159.6655 & 39.37789 \\
\hline Valid N & $\mathbf{1 1}$ & & & & \\
(listwise) & & & & & \\
\hline Sumber : & & & & &
\end{tabular}

Sumber : Data diolah , 2018

\section{Statistik Deskriptif Kurs Mata Uang Dunia Terhadap Dollar}

Hasil statistik deskriptif data kurs mata uang dunia terhadap dollar dari 14 negara sebagai berikut:

Tabel 3

Statistik Deskriptif 14 Kurs Mata Uang Terhadap Dollar

\begin{tabular}{lcrrrr}
\hline & N & Minimum & Maximum & Mean & $\begin{array}{c}\text { Std. } \\
\text { Deviation }\end{array}$ \\
\hline BRITISHPOUND & 11 & 0.79 & 0.81 & 0.8027 & 0.00647 \\
EURO & 11 & 0.90 & 0.93 & 0.9145 & 0.01214 \\
SWISS & 11 & 0.97 & 1.00 & 0.9845 & 0.01214 \\
AUSDOLLAR & 11 & 1.29 & 1.34 & 1.3118 & 0.01662 \\
CANDOLLAR & 11 & 1.33 & 1.36 & 1.3436 & 0.00809 \\
NZDOLLAR & 11 & 1.36 & 1.41 & 1.3845 & 0.01968 \\
SINGDOLLAR & 11 & 1.38 & 1.42 & 1.3991 & 0.01578 \\
RIYAL & 11 & 3.75 & 3.75 & 3.7500 & 0.00000 \\
YUAN & 11 & 6.75 & 6.88 & 6.8027 & 0.04407 \\
DANISH & 11 & 6.69 & 6.96 & 6.8109 & 0.10464 \\
HKDOLLAR & 11 & 7.75 & 7.76 & 7.7591 & 0.00302 \\
NORWEGIAN & 11 & 8.17 & 8.50 & 8.3236 & 0.12902 \\
SWEDISH & 11 & 8.90 & 9.19 & 9.0536 & 0.10259 \\
JAPANES & 11 & 103.03 & 109.13 & 105.7727 & 2.28311 \\
\hline Valid N (listwise) & $\mathbf{1 1}$ & \multicolumn{5}{c}{} \\
\hline \multicolumn{5}{c}{ Sumber : Data diolah , 2018 }
\end{tabular}


INOBIS: Jurnal Inovasi Bisnis dan Manajemen Indonesia

Volume 1, Nomor 4, September 2018

Meina Wulansari Yusniar; Sulfi Jikrillah

\section{Hasil Pengujian Hipotesis}

\section{a) Pengujian Hipotesis 1}

Pengujian hipotesis pertama dilakukan untuk mengetahui kandungan informasi pada pengumuman kemenangan Donald Trump sebagai presiden AS terhadap 8 (delapan) Bursa Saham selama periode Jendela.

\section{Uji Hipotesis Pertama}

$\mathrm{H}_{0}$ : Tidak terdapat perbedaan harga saham yang signifikan selama periode jendela pada 8 (delapan) bursa saham.

$\mathrm{H}_{1}$ : Terdapat perbedaan harga saham yang signifikan selama periode jendela pada 8 (delapan) bursa saham.

Dalam melakukan uji beda, data harus memenuhi asumsi dari uji beda yaitu sampel yang diambil berdistribusi normal atau mendekati normal atau bisa dianggap normal. Dalam penelitian ini, pengujian normalitas data menggunakan Uji Shapiro Wilk Test karena jumlah data kurang dari 50. Tabel 4 menunjukkan bahwa data berdistribusi normal karena nilai signifikan di bawah dari $>0,05$.

\section{Tabel 4}

Hasil Uji Normalitas Data Harga Saham

\begin{tabular}{|c|c|c|c|c|c|c|}
\hline \multicolumn{7}{|c|}{ Tests of Normality } \\
\hline & \multicolumn{3}{|c|}{ Kolmogorov-Smirnov ${ }^{\mathrm{a}}$} & \multicolumn{3}{|c|}{ Shapiro-Wilk } \\
\hline & Statistic & df & Sig. & Statistic & $\mathrm{df}$ & Sig. \\
\hline SEBELUM & 0.256 & 8 & 0.132 & 0.838 & 8 & 0.072 \\
\hline SESUDAH & 0.254 & 8 & 0.138 & 0.839 & 8 & 0.073 \\
\hline
\end{tabular}

a. Lilliefors Significance Correction

Sumber : Hasil SPSS, data diolah 2018

Karena data berdistribusi normal, maka dilakukan uji Paired Sample t-Test dilakukan yang hasil pengujian dapat dilihat pada tabel 5 berikut. Pada tabel 5. dapat disimpulkan bahwa $\mathrm{H}_{1}$ ditolak, dan Ho diterima berarti bahwa tidak ada perbedaan harga saham dunia sebelum dan sesudah terpilihnya Donald Trump sebagai presiden AS.

\section{Tabel 5}

Hasil Uji Paired Sampel Test terhadap Harga Saham Paired Samples Test

\begin{tabular}{|c|c|c|c|c|c|c|c|c|c|}
\hline \multicolumn{10}{|c|}{ Paired Samples Test } \\
\hline & & \multicolumn{5}{|c|}{ Paired Differences } & \multirow[b]{3}{*}{$\mathbf{t}$} & \multirow[b]{3}{*}{ df } & \multirow{3}{*}{$\begin{array}{l}\text { Sig. (2- } \\
\text { tailed) }\end{array}$} \\
\hline & & \multirow[b]{2}{*}{ Mean } & \multirow{2}{*}{$\begin{array}{c}\text { Std. } \\
\text { Deviation }\end{array}$} & \multirow{2}{*}{$\begin{array}{c}\text { Std. Error } \\
\text { Mean }\end{array}$} & \multicolumn{2}{|c|}{ Interval of the } & & & \\
\hline & & & & & Lower & Upper & & & \\
\hline Pair 1 & $\begin{array}{l}\text { SEBELUM - } \\
\text { SESUDAH }\end{array}$ & -89.25000 & 242.45810 & 85.72188 & -291.95004 & 113.45004 & -1.041 & 7 & 0.332 \\
\hline
\end{tabular}

Sumber : Hasil SPSS, data diolah 2018 
INOBIS: Jurnal Inovasi Bisnis dan Manajemen Indonesia

Volume 1, Nomor 4, September 2018

Meina Wulansari Yusniar; Sulfi Jikrillah

\section{b) Pengujian Hipotesis 2}

Pengujian hipotesis kedua dilakukan untuk mengetahui kandungan informasi pada pengumuman kemenangan Donald Trump sebagai presiden AS terhadap 14 kurs Mata Uang dunia terhadap dollar Amerika selama periode Jendela.

\section{Uji Hipotesis Kedua}

$\mathrm{H}_{0}$ : Tidak terdapat perbedaan nilai tukar mata uang yang signifikan selama periode jendela pada 14 kurs mata uang terhadap dollar.

$\mathrm{H}_{2}$ : Terdapat perbedaan nilai tukar mata uang yang signifikan selama periode jendela pada 14 mata uang negara terhadap dollar.

Dalam melakukan uji beda, data harus memenuhi asumsi dari uji beda yaitu sampel yang diambil berdistribusi normal atau mendekati normal atau bisa dianggap normal. Dalam penelitian ini, pengujian normalitas data menggunakan Uji Shapiro Wilk Test.

Tabel 6

Hasil Uji Normalitas Nilai Tukar Mata Uang Tests of Normality

\begin{tabular}{|l|c|c|c|c|c|c|}
\hline \multirow{2}{*}{} & \multicolumn{3}{|c|}{ Kolmogorov-Smirnov } & \multicolumn{3}{c|}{ Shapiro-Wilk } \\
\cline { 2 - 8 } & Statistic & df & Sig. & Statistic & df & Sig. \\
\hline SEBELUM & 0.459 & 14 & 0.000 & 0.393 & 14 & 0.000 \\
\hline SESUDAH & 0.460 & 14 & 0.000 & 0.391 & 14 & 0.000 \\
\hline
\end{tabular}

a. Lilliefors Significance Correction

Sumber : Hasil SPSS, data diolah 2018

Berdasarkan tabel 6. diketahu bahwa data berdistribusi tidak normal karena nilai signifikansinya $<0,005$. Karena data tidak berdistribusi normal, maka dapat dilakukan uji beda Paired Sampel Test dengan uji Wilcoxon. Adapun hasil uji paired sampel test yang menjelaskan analisis terhadap ada atau tidaknya perbedaan nilai tukar mata uang sebelum dan sesudah pengumuman kemenangan Donald Trump sebagai presiden AS dapat dilihat pada tabel 7. Berdasarkan tabel 7 diketahui bahwa hipotesis kedua diterima yang berarti terdapat perbedaan nilai tukar mata uang yang signifikan selama periode jendela pada 14 mata uang negara lain terhadap dollar. Nilai $\mathrm{Z}$ yang negatif menandakan bahwa pasar uang bereaksi negative terhadap kemenangan presiden Donald Trump sebagai Presiden Amerika Serikat. Hampir semua kurs mata uang 14 negara mengalami pelemahan terhadap dollar Amerika.

Tabel 7.

Hasil Uji Paired Sampel Test -Wilcoxon terhadap Kurs Mata Uang Test Statistics $^{\mathrm{a}}$

\begin{tabular}{|l|r|}
\hline & \multicolumn{1}{|c|}{ SESUDAH - SEBELUM } \\
\hline \hline Asymp. Sig. (2-tailed) & $-2.947^{\mathrm{b}}$ \\
\hline \hline a. Wilcoxon Signed Ranks Test & 0.003 \\
\hline b. Based on negative ranks. \\
\hline
\end{tabular}


INOBIS: Jurnal Inovasi Bisnis dan Manajemen Indonesia

Volume 1, Nomor 4, September 2018

Meina Wulansari Yusniar; Sulfi Jikrillah

\section{Pembahasan}

Penelitian ini bertujuan untuk mengetahui reaksi pasar keuangan dalam hal ini pasar modal dan pasar uang dunia terhadap peristiwa politik yaitu terpilihnya Donald Trump sebagai Presiden Amerika Serikat ke 45 pada tanggal 8 November 2016. Berdasarkan hasil penelitian diketahui bahwa dari 8 bursa saham dunia yang dijadikan sebagai sampel penelitian tidak ada perbedaan yang signifikan antara harga saham bursa sebelum dan sesudah peristiwa politik tersebut. Namun jika melihat dari nilai harga saham gabungan dari 8 bursa dunia diketahui bahwa terjadi perubahan nilai saham sebelum dan sesudah peristiwa pemilihan presiden Amerika Serikat namun secara statistik perbedaan itu tidak signifikan. Hal ini memperlihatkan bahwa investor pasar modal lebih cepat menyesuaikan respon mereka terhadap harga saham dunia. Pada saat pengumuman Kemenangan Donald trump sebagai Presiden Amerika Serikat, Indeks harga Saham 8 bursa dunia mengalami penurunan yang cukup tajam yaitu sekitar 2 persen dari hari sebelumnya. Hal ini sebenarnya merupakan efek psikologi sesaat dari investor yang masih berharap Hillary Clinton terpilih sebagai Presiden AS. Tetapi 1 hari setelah pengumuman Presiden AS harga saham mulai terkoreksi ke harga sebelum pengumuman Kemenangan Presiden.

Hal berbeda ditunjukkan di Pasar Uang Dunia dimana hasil penelitian memperlihatkan bahwa pasar Uang Dunia bereaksi negatif dan Signifikan terhadap Peristiwa Kemenangan Donald Trump sebagai Presiden Amerika Serikat. Hal ini terlihat bahwa hampir sebagian besar nilai tukar 14 mata uang asing yang dijadikan sebagai sampel terhadap mata uang dollar mengalami pelemahan. Menguatnya nilai mata uang dollar terhadap mata uang asing diperkirakan karena janji kampanye Donald Trump akan memprioritaskan warga Amerika Serikat. Kebijakan Trump seperti deportasi imigran ilegal, pemutusan hubungan perdagangan dengan tiongkok serta pemangkasan tax ratio, akan memberikan pengaruh yang negatif pada perekonomian global. Dampaknya, investor dan pialang Amerika Serikat langsung menarik dananya di berbagai belahan dunia untuk dialihkan di pasar keuangan dan pasar modal Amerika Serikat . Seiring dengan mengalirnya modal ke pasar Amerika Serikat, permintaan dollar AS pun mengalami peningkatan. Hal ini mengakibatkan nilai tukar mata uang beberapa negara berpotensi cenderung melemah atau dengan kata lain kurs dollar AS mengalami penguatan. Dari sisi perdagangan dan industri, adanya kebijakan perdagangan dan industri yang proteksionisme yang dilakukan oleh Donald Trump akan berdampak negatif bagi ekspor beberapa Negara ke Amerika Serikat karena pemerintah AS berencana untuk mengenakan bea impor 100 persen, sehingga akan menghambat impor barang dari Negara Negara lainnya ke Amerika. Hasil penelitian ini, sejalan dengan penelitian dari Malaver (2017) yang menemukan bahwa pemilihan Presiden Amerika berdampak negatif terhadap nilai tukar mata uang Peso terhadap Dollar US yang mengarah kepada inefisiensi pasar dan arbitrase.

\section{Simpulan}

Berdasarkan Analisis dan pembahasan penelitian mengenai reaksi pasar keuangan terhadap peristiwa politik dalam hal ini Pemilihan Presiden AS ditemukan bahwa tidak terdapat perbedaan yang signifikan antara harga saham bursa dunia sebelum dan sesudah peristiwa pemilihan Presiden Amerika Serikat. Namun untuk nilai kurs mata uang Asing terhadap dollar terdapat perbedaan yang negatif dan signifikan terhadap peristiwa Pemilihan Presiden Amerika Serikat. Hasil penelitian ini memperlihatkan bahwa pasar saham dunia tidak bereaksi berlebihan terhadap hasil pemilihan presiden AS pada tanggal 11 November 2016. Investor pasar modal lebih cepat menyesuaikan respon mereka terhadap harga saham 
INOBIS: Jurnal Inovasi Bisnis dan Manajemen Indonesia

Volume 1, Nomor 4, September 2018

Meina Wulansari Yusniar; Sulfi Jikrillah

dunia, sehingga indeks harga saham sebelum dan sesudah peristiwa tidak berbeda secara signifikan. Sebaliknya, pasar uang dunia memberikan reaksi negative dan signifikan terhadap pemilihan presiden Amerika Serikat. Reaksi tersebut disebabkan karena investor di pasar uang menilai kebijakan yang akan diambil oleh presiden terpilih tidak menguntungkan bagi beberapa negara sehingga nilai tukar mata uang dari beberapa negara terhadap mata uang dollar AS mengalami pelemahan.

\section{Referensi}

Asshodiqi, A. 2015. Reaksi Pasar Modal Terhadap Peristiwa Pelantikan Presiden Tahun 2014 (Event Study Pada Saham LQ45, JII, dan SMINFRA18). Jurnal Ilmiah. Fakultas Ekonomi dan Bisnis Universitas Brawijaya. Malang

Ashour, S dan Sarkar, S. 2014, U.S. Presidential Cycle and Foreign Exchange Market

Benhar,W dan Leblang,D. 1999. Political Processes and Foreign Exchange Markets. Annual Meetings of the American Political Science Association,Atlanta, GA

Gemmill, G. 1992. Political risk and market efficiency: tests based in British stock and options markets in the 1987 election. Journal of Banking \& Finance, 16(1), 211-231

Hartono, J. 2013. Teori Portofolio dan Analisis Investasi. Edisi 7. BPFE. Yogyakarta.

Henderson, G.V. 1990. Problems and Solutions in Conducting Event Studies. Journal of Risk and Insurance, Vol. 57 No.2 (June), 282-306.

Kabiru, J. N, Ochieng, Duncan, E dan Kinyua, H.W. 2015. The Effect of General Elections on Stock Return At the Nairobi Securities Exchange, European Scientific Journal October 2015 edition vol.11, No.28 ISSN: 1857 - 7881 (Print) e - ISSN 1857- 7431

Malaver, M, 2017. Measuring the Impact of President Donald Trump's Tweets on the Mexican Peso/U.S. Dollar Exchange Rate, Major Paper presented to the Department of Economics of the University of Ottawa

Meidawati, Neni dan Harimawan, M. 2004. Pengaruh Pemilihan Umum Legislatif Indonesia Tahun 2004 Terhadap Return Saham dan Volume Perdagangan Saham LQ-45 di PT. Bursa Efek Indonesia (BEJ)",SINERGI Kajian Bisnis dan Manajemen, Vol 7 No. 1, 89-101.

Mendelson, M. 1976. Investment Analysis and Security Markets New York : Basic Books

Nezerwe, Yvan. 2013. Presidential Election and Stock Return in Egypt, Review Of Business and Finance Studies, Volume 4 Number 2

Ochieng, A. S. 2013. The Effect of political Risk on Exchange Rates in Kenya, Research Project Submitted in Partial Fulfillmeent of The Requirements for the Degree of Master of Science in Finance, University of Nairobi

Oehler, A, Thomas J. W dan Wendt, (2009), Effects of Election Results on Stock Price Performance: Evidence from 1976 to 2008

Peel, D. \& Pope, P. (1983). General Election in the U.K. in the Post-1950 Period and the Behavior of the Stock Market, Investment Analysis 67, 4-10.

Suryawijaya, Marwan, A dan Faizal A.S. 1998. Reaksi Pasar Modal Indonesia Terhadap Peristiwa Politik Dalam Negeri (Event Study pada Peristiwa 27 Juli 1996), KELOLA, Vol.VII, No.18, h.137-153.

Tandelilin, E. 2010. Portofolio dan Investasi. Edisi pertama. Yogyakarta: Kanisius

Trisnawati, F. 2014. Pengaruh Peristiwa Politik Terhadap Perubahan Volume Perdagangan Saham dan Harga Saham. Jurnal. Program Magister 
INOBIS: Jurnal Inovasi Bisnis dan Manajemen Indonesia

Volume 1, Nomor 4, September 2018

Meina Wulansari Yusniar; Sulfi Jikrillah

Manajemen Ilmu Ekonomi. Program Pascasarjana Bidang Kajian Utama Akuntansi Universitas Padjadjaran. Bandung

Triyono. 2008. Analisis perubahan Kurs Rupiah Terhadap Dollar Amerika. Ekonomi pembangunan Vol. 9, No. 2, Desember

Zaqi, Mochamad, 2006, Reaksi Pasar Modal Indonesia terhadap Peristiwa-Peristiwa Ekonomi dan Peristiwa- Peristiwa Sosial-Politik Dalam Negeri, Tesis UNDIP, tidak dipublikasikan. 